Nikolay S. Mironenko ${ }^{1 *}$, Tatyana Kolchugina ${ }^{2}$

${ }^{1 *}$ Head of the Department of Geography of World Economy, Faculty of Geography, M.V. Lomonosov Moscow State University; e-mail: nikolay_mironenko@mail.ru (Corresponding author)

${ }^{2}$ President, Sustainable Development Technology Corporation, Corvallis, Oregon, USA; e-mail: kolchut@gmail.com

\title{
EXPORT-ORIENTED MODEL
}

\section{OF SUSTAINABLE DEVELOPMENT}

IN RUSSIA (FROM THE "DUTCH DISEASE" TO INNOVATIVE DEVELOPMENT)

\begin{abstract}
This article analyzes the "Dutch disease" as a significant barrier to sustainable associated with the presence in the country of large hydrocarbon resources and their enhanced export. Rybczynski's theorem was used to demonstrate negative effects of the "Dutch disease" in advancement of processing industrial sectors. The "oil-shale revolution" that occurs mainly in the U.S. and represents a threat even for the Russian export of natural gas and oil, has been analyzed. A liberal export-oriented model of Russia's participation in the international division of labor may help overcoming this unstable situation.
\end{abstract}

Key words: "Dutch disease", "oil-shale revolution", export-oriented model, sustainable economic development, Russia

\section{INTRODUCTION}

Russia's economic development and effective reintegration into the global economy after the collapse of the militaryindustrial structure (in terms of the territorialsectoral organization and the composition of products) during the period of perestroika and the collapse of the former Soviet Union, was based on the exploitation of considerable reserves of fuel and raw materials diverse in composition. There have been massive changes in the macrostructure of both production and exports. The country has been taken in the toils of the hard-to-treat (but still curable) "Dutch disease" that has been relevantly described by the theorem of an English economist T.M. Rybczynski [1955] that has become the "classics" of economic thought. Its meaning is quite simple and is based on the notion that the transfer of resources (investment, labor, and other production factors) from the manufacturing sector to the secondary (raw) and to the tertiary (non-productive sphere) lowers the added value. Rybczynski has logically and mathematically proven and has illustrated graphically that the sector of the economy where the cheapened production factor is most intensively used "drains" mobile production factors away from another sector. At constant prices and availability in the economy of only two sectors (theoretical assumption), the growth of one of the production factors leads to the reduced production of the other commodity. Expansion of the "hydrocarbon" areas (as a redundant factor of production and, hence, of exports) leads to drop in the rate of growth in other sectors and increases the instability of the economy as a whole. This is expressed primarily in deindustrialization. Further empirical studies have shown that the higher the proportion of the resource component in the GDP, the less incentive there is to move forward - to 
the development of an innovative economy. The "Dutch disease" in Russia takes a long course and a serious form: with a focus on growth in the world prices for hydrocarbons and a manifestation of the "narrowminded" mentality, whose attributes are complacency and underestimation of the need for fundamental changes in the nature of Russia's participation in the international division of labor. There is another threat to economic stability in Russia, which the country can face even in the near future - the "oil-shale revolution" taking place rapidly in the U.S., which may allow moving away from the traditional paradigm of oil and gas production. Shale hydrocarbon reserves may change both the geoeconomic and geopolitical structure of the world. The way out of the emerging world situation can be a model of sustainable economic development in the international and transnational division of labor. A break from a "vicious circle" can be found in historical and geographical study of similar processes and methods of overcoming them. The paper proposes a purely preliminary idea of Russia's preferred orientation for a gradual engagement with countries-leaders/innovators in the modern economy of the world system. A logical scheme of the implementation stages of the process of integrating the Russian economy into the global economy is provided in support of this approach.

\section{DATA AND METHODS}

Material for this article is based on discussions of the future of sustainable world economy, including Russia, in national and foreign scientific publications and periodicals that are becoming increasingly intense in the time of crisis. The basic method is a set of logical arguments arising from the experience of observing reality and adhering to the rules of theoretical approaches prevailing in the social geography used to test different positions towards occurring events and potential to determine their possible development at least in the short term.

\section{RESULTS AND DISCUSSION}

The history of economic development shows that individual countries can get rich quick by a sudden discovery of large reserves of raw materials and energy resources. It is possible to increase the level of exports with significant growth of the world prices for resources already developed. This situation, for example, was characteristic of OPEC in the 1970s and the subsequent crisis "peaks" of supply and demand for oil in the world markets.

The effect of large changes due to the discovery of new reserves and increase of their prices have such a negative effect on the macrostructure of the economy, on the level and direction of foreign investment, on the composition of exports, and on the exchange rate of the country, that the magazine "Economist" in 1977 [Economist, 2010] named this effect the "Dutch disease". The name is associated with the discovery in the Netherlands in 1959, of several fields of natural gas. This was followed by the decline in manufacturing exports and the increase in inflation and unemployment. The additional foreign exchange inflow in the mining sector has eventually led to real currency appreciation and, consequently, increased domestic and export prices. In the long term, the "Dutch disease" leads to a transfer of resources from the manufacturing sector to the raw materials sector and to the tertiary sector. The latter sectors create less added value, which lowers the total GDP of a country.

A more intuitive explanation of the mechanism of the "Dutch disease" can be obtained using Rybczynski's theorem and the following assumptions: constant prices and the availability of only two sectors of the economy. Based on these assumptions, the quantitative growth of one of the factors of production (capital, labor, land) leads to the reduced production volumes of the other sector of the economy [Rybczynski, 1955; Kireev, 1997; Zabelina, 2004]. Moving the economic resources to oil and gas production over a certain time-period results in increase 
in income of the population. The subsequent growth of prices for oil and gas leads to a new phase of the "Dutch disease" associated with reduction in personal income, with transfer of resources from the fuel sector, and, once again, with strengthening of the positions of the traditional export sectors of manufacturing industry.

Thus, according to Rybczynski's theorem, the "Dutch disease" leads, over one timeinterval or another, to a reduction of the production of non-resource goods export. As already noted, this is due to the fact that the GDP growth during the boom in the extraction of natural resources leads to an outflow of capital (investment) from the earlier traditional, for the country, export manufacturing activity and its inflow to the primary (resource) sector. In 1981, this phenomenon was investigated in detail by Ellman [Ellman, 1981] whose work has been devoted not so much to the problems of connection of the discovery of large deposits of oil and gas with the increase in foreign exchange rates, but rather to inefficient investments by the state petroleum revenues into the social sphere. Empirical analysis of the U.S. researchers J. Sachs, A. Warner, and F. Larrain [Sachs and Warner, 1995; Sachs and Larrain, 1996] of the correlation between the share of the resource sectors in the GDP and the rate of economic growth (over a period of a very high growth in the world trade due to lower prices for goods transportation in 1970-1990) have established the presence of feedback and arrived at the conclusion that the greater the share of the resource component of the GDP, the less incentive there is to move forward. Later, such terms as "resource curse" and "paradox of plenty" have entered even in the economic literature.

Russia is a "hydrocarbon" country based on its economic structure. It is only natural that the Russian economy was struck by the "Dutch disease". The GDP growth is mainly provided by higher energy prices, which reduces Russia's competitiveness in the international division of labor and leads to significant risks to economic security. And the risks are increasing due to Russia's role as a superpower in the global geopolitics (with some reservations); the country, along with the U.S., determines the balance of forces in the system of the global order.

The "Dutch disease" in Russia is long-drawn and very severe (the Netherlands were "sick" for a shorter time in comparison with Russia - for slightly less than a decade). The pressure of hydrocarbon exports on the domestic economy significantly reduces its competitiveness in the world economy. Moreover, a severe form of the disease leads to the degradation and even loss of propulsive high-tech industries. Drop in profitability in high-end industries due to increasing pressure of hydrocarbon exports leads not only to technological backwardness, but also to preservation of the necroeconomy that brings irrelevant or even unwanted goods to market and is not in need of a major upgrade of technology and of inflow of foreign investment [Papava, 2009]. Given the current situation, which has long-term inertia, there is an acute problem of scenarios (models) of the development of the Russian economy in the next 15-20 years.

Another factor threatening the economic stability of Russia may be the so-called "oilshale revolution" widely discussed in scientific publications and the media. This revolution (sometimes it is called the "oil-shale rush" by analogy with the largest "gold rush" in the U.S. in the XIXth century in Northern California and Alaska). The "shale revolution" is primarily associated with the territory of the U.S. and more precisely, with the Bakken formation (Wyoming, Montana, and North Dakota). The second largest oil-shale field is the Niobrara formation (in the borderlands of Dakota and Nebraska). The total potential reserves of oil-shale is estimated at 650 trillion tons, of which 430-450 trillion tons are in the United States (Colorado, Utah, Wyoming) [Shale industry in Russia, 2011].

Russia occupies the second place, followed by Brazil. Russia has $12-13 \%$ of the world oil reserves, $42 \%$ of natural gas, about $20 \%$ 
of black coal, and $32 \%$ of other coals, not considering the huge stocks of alternative fuels, which include oil-shale [Shale industry in Russia, 2011]. In Russia, the largest known oil-shale deposits are located in the Leningrad region, the Volga region, and in the Timan-Pechora and the Vychegda Basins. However, their development needs investment, especially in exploration and new technologies.

In the U.S., technology that increases profitability of oil and gas extraction is being intensively developed. Great potential, partly implemented, in the oil and natural gas sector in the U.S. may prevent hydrocarbons produced in Russia from entering largest markets in North America, Canada, and possibly, in Europe. While there are discussions about the "shale revolution", the flow of information in press on the intensive exploration of the Bakken oil formation and on a sharp decline of its cost of production is gaining momentum. A possibility that companies specializing in oil and gas production from shale will become largest players in the world hydrocarbon market should not be excluded. With the sharp growth of supply, prices will drop dramatically.

Many well-founded models are built on the ideas of moderate liberalism. They are based on the notion of self-development of the national economy in transition (transformation) to the highest and best forms with full participation in global and regional processes of the international division of labor. As noted by V.L. Tsymbursky, a liberal (great in his account) worldview is: "The world, as it is, has originated by some coincidence. Disrupting the balance of this world, interfering with its operation, we run the risk of plunging it into chaos and disintegration". This is absolutely the opposite thesis to the one that the socialists and a number of liberals, or rather, liberals of Keynesian persuasion, conform to. "From the standpoint of socialism, nothing good will become of this world, if we do not construct and do not build it" [Tsymbursky, 2001].
The way out of this situation, out of the "vicious circle" of different world's views, in our opinion, is historical-geographical study of specific processes of progress in specific countries and regions. All countries that have made significant strides in the progress of the economy and society as a whole, with all the nuances of the methods of achieving them adhere, to some extent, to the ideas of liberalism and have certainly participated in the international division of labor. For Japan and newly industrialized countries that do not have on their territories a variety of significant stocks of raw materials and fuel (and therefore free from the "Dutch disease"), a leading factor in the progress of their policy is the successive (cascade) integration into such a powerful planetary process as the international geographic division of labor. In order to fully participate in the process of internationalization/globalization on the basis of division of labor, these countries (and now their followers that have rejected the antiliberal protectionism and import substitution) have conducted a major anti-feudal reform, have created the institution of private property, and have entered the democratic principles of the functioning of society.

Their preferred orientation towards foreign economic cooperation with leading countries/economic innovators in the world economy has become the main road of progress (modernization). Analysis of the experience of integration into the global economy of Japan shows that a countryfollower (at the start, a country of imitation) consistently exports, to countries-leaders, goods whose production in the countryfollower is cheaper and the quality is equal and sometimes is better than the in the countries-leaders.

If a country-follower chooses a different path, i.e. the orientation of its economy towards markets of economically less developed countries that impose the demand for cheap and outdated products, modernization of society and technological progress in this country-follower are virtually impossible [Maksakovskyi, 2003; Portnoy, 1996]. 

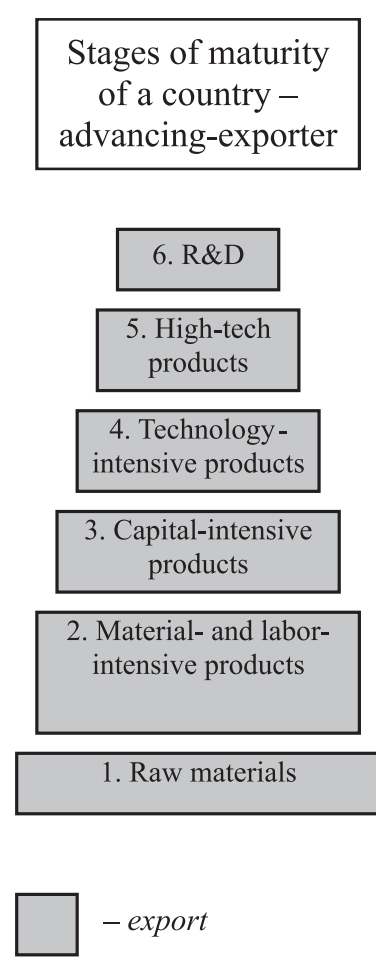

Structure of economy of a country-leader
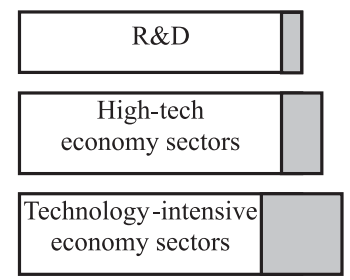

Capital-intensive economy sectors

Material- and labor-intensive economy sectors

Raw materials

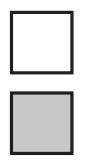

- domestic production - import from a country-follower

Fig. 1. Schematic representation of the implementation of the process of integration of a countryfollower's economy into the world's economy (R\&D stands for research and development). The export-oriented model of development (based on [Portnoy, 1996])

Based on the "ideology" of foreign economic cooperation with leading countries, a country-follower acts in time with the principles of liberalization, finding its place in the self-development of the world "to the highest and best forms". The scheme of implementation of the integration of a country-follower's economy into the world economy is presented in Fig. 1 with a brief explanation afterwards.

The first stage. A country does not have goods competitive on the world commodity market or has inadequately competitive goods. However, it has raw and primary materials. Such countries include Russia, with its diverse and vast potential of natural resources. The raw materials and fuel exports at this country's early state of the reintegration into the global economy is inevitable. However, this type of exports in the overall strategy of participation in the international division of labor should be considered as the first step in cooperation with foreign countries and multinational corporations; major stages of production are in those countries. Since the revenue from the industries of the primary sector and foreign direct investment are the main sources of modernizing the subsequent (according to the rank) industries (manufacturing in the broadest sense), such approach is a strong argument in favor of this idea.

The second stage. At this stage, the country becomes an exporter of material- and laborintensive goods that outcompete the raw material component for the important position in the economy. The most common 
goods of exports: oil, high quality building materials, textiles, chemical products, clothing, shoes, etc.

The third stage. By modernizing the subsequent, according to the ranking, industrial sectors, the country is becoming an exporter of capital-intensive goods. Typical products: steel rolling, forge-and-pressing equipment, construction machinery, and ships.

The fourth stage. The country exports technology-intensive products: machine tools, production lines, turbines, automobiles, buses, and measuring tools and instruments.

The fifth stage. The country is exporting a wide range of high technology products: electrical, electronic, and aerotechnics products, communication equipment, new construction materials, etc.

The sixth stage. As a final step - cooperation in research and development.

This scheme is not straight-lined, but quite logical. Without strong modern metallurgy and engine building, it is impossible to become a producer and an exporter of domestic cars. The logic nature of the scheme is supported by the experience of postwar Japan and the Republic of Korea. However, the specifics of these two countries, unlike in Russia, is in the fact that, in the absence of any significant stocks of raw materials and fuel, they do not have to overcome huge diseconomies associated with the "Dutch disease". Therefore, the advancement of the Japanese and the South Korean exports up the steps of the technological ladder went from light industry to the prevailing export of machinery and equipment. Such a rise took fifteen to twenty years in Japan and, as a country-follower, it went through the stages of "textile", "steel", "car", and "semiconductor" "wars" with the countries-leaders; with the renovation of its automobile construction section beginning in the 1990s, it entered into a new "car war" till it carried out a widespread penetration into the U.S. of its transnational corporations in the form of "trans-plant" corridors [Philip and North, 1991].

Interaction of Japan (a country-imitator of advanced technologies and institutional infrastructure) with the U.S. (an innovative leading country) contributed to the restructuring and to the socioeconomic sustainability of both countries.

\section{CONCLUSIONS}

1. A public policy aimed at overcoming the "Dutch disease" associated with the marked predominance (40\%) in domestic exports of fuel and commodities may become a real catalyst for transformation in achieving sustainable economic structures in Russia. The so-called "shale revolution" predicted by scientists can contribute to restructuring of the economy in general and of its export component in particular. It can produce a significant supply of energy to the world market, which will inevitably lead to a reduction in its prices. This, in turn, can lead to a dramatic reduction in the quality of life of the Russian population.

\section{If earlier, the "Dutch disease" has spread} to individual, mainly small and medium advanced countries in the context of regional-scale discovery of oil and gas fields, the "shale revolution" could become a disease of global proportions. This may break the existing relative balance of supply and demand in this sector, which plays a major role in the alignment of the geoeconomic and geopolitical balance of power in the world.

3. Rybczynski's theorem has been repeatedly confirmed (with certain deviations). The case of the deindustrialization of the Netherlands and other countries has become a textbook example. Therefore, the principles of this theorem can spread practically to the entire world and have negative consequences at the level of so-called large spaces. 
4. As a proposal of overcoming the state of anxiety and uncertainty about the threat of instability, the experience of the countries that have overcome the "Dutch disease" should certainly be taken into account. However, alone that is not sufficient. Here, the scheme of creation of the export-oriented model of Russia's entry into the international division of labor is suggested. In the authors' opinion, a step-by-step progression up the larger stages of the integrated foreign economic cooperation between Russia and the leading countries are as follows: cooperation at the level of fuel and raw materials; transition to the stage of material- and labor-intensive products; then, to the stage of capitalintensive goods; further, to the technologyintensive stage. The last two stages are related to the area of high technologies and research and development. Consistency and appropriateness of the scheme is supported by practice of the use of the factor of the international division of labor by Japan, and later, by the newly industrialized countries.

\section{REFERENCES}

1. Economist (2010). Sept. 9, 2010. (http://www.economist.com/node/16964094; Retrieved January 15, 2012).

2. Ellman, M. (1981). Natural gas, re-structuring, and re-industrialization: the Dutch experience of policy // Oil or Industry? London, pp. 27-29.

3. Kireev, A. (1997). International economics: the flow of goods and of production factors. Part one. pp. 173-174. (in Russian).

4. Maksakovskyi, V.P. (2003). Models of the Japanese economy // Geography at school. № 10, pp. 26-31. (in Russian).

5. Papava, V. (2009). Financial crisis and post-communist capitalism // World Economy and International Relations. 2009. № 8, pp. 89-95. (in Russian).

6. Philip, N. J. and J. North (1991). Japanese motor industry transplants: the West European dimension. Economic Geography, Vol. 67, No. 2 (Apr., 1991), pp. 105-123 (http://www. jstor.org/pss/143540; Retrieved January 18, 2012).

7. Portnoy, M. (1996). The trade strategy of Russia and the international experience // World Economy and International Relations. pp. 45-53. (in Russian).

8. Rybczynski, T. M. (1955). Factor endowments and relative commodity prices // Economica, 22, № 84, pp. 336-341.

9. Sachs, J. and A. Warner. (1995). Natural resource abundance and economic growth // Working Paper. № 5398, pp. 40-61.

10. Sachs, J.D. and F.B. Larrain. (1996). Macroeconomics. A Global Approach. St Petersburg. 847 p. (in Russian).

11. Shale industry in Russia (2011) (http://newchemistry.ru/letter.php?n_id=6816 retrieved January 14, 2012).

12. Tsymbursky, V.L. (2001). On the seminar on the conservatism of the Russian Cultural Foundation // Problems of Philosophy. № 8, p. 168 (in Russian).

13. Zabelina, O. (2004). The Russian specifics of the "Dutch disease" // Problems of Economics. № 4, pp. 21-32. (in Russian). 

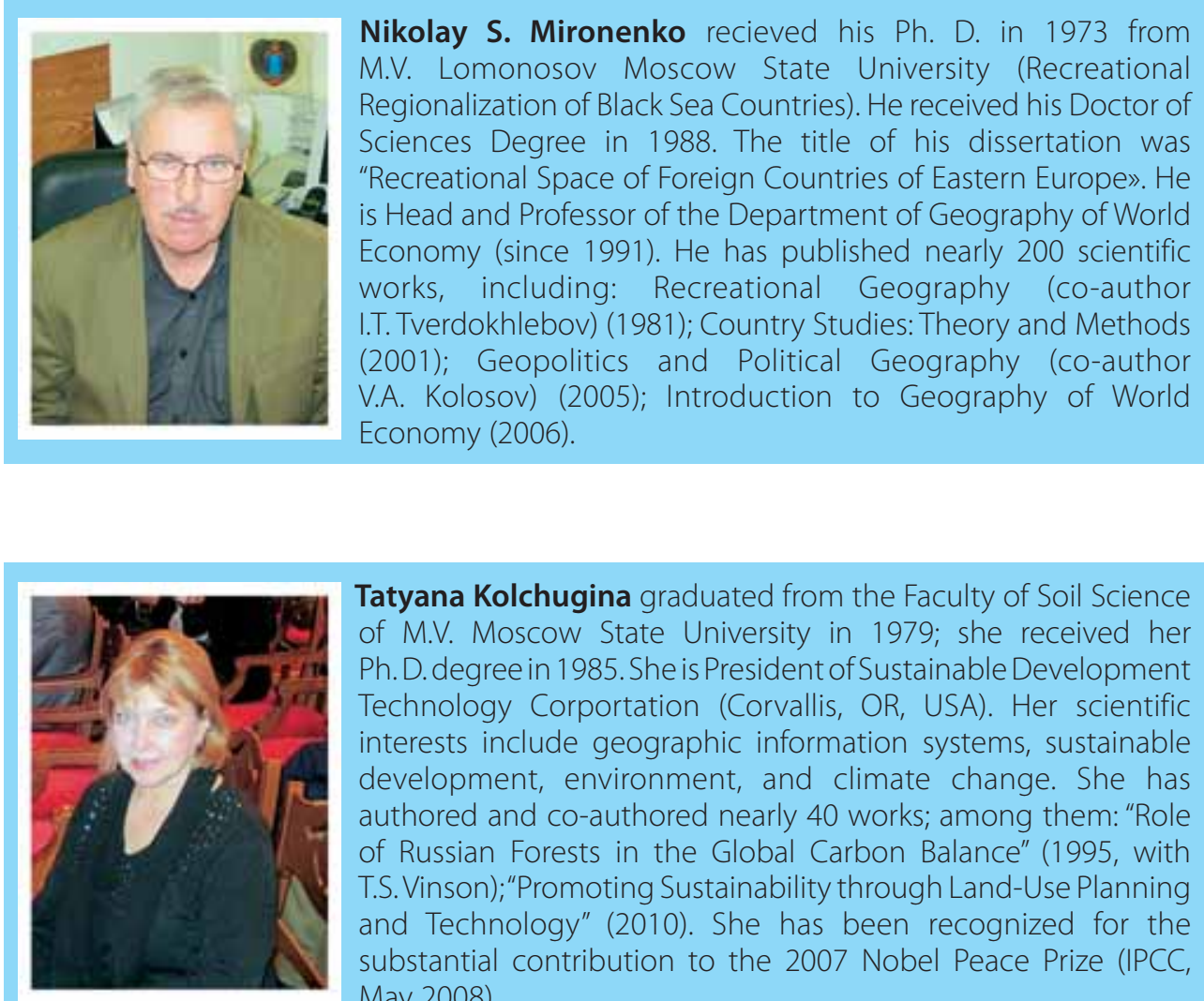

Tatyana Kolchugina graduated from the Faculty of Soil Science of M.V. Moscow State University in 1979; she received her Ph. D. degree in 1985. She is President of Sustainable Development Technology Corportation (Corvallis, OR, USA). Her scientific interests include geographic information systems, sustainable development, environment, and climate change. She has authored and co-authored nearly 40 works; among them: "Role of Russian Forests in the Global Carbon Balance" (1995, with T.S. Vinson); "Promoting Sustainability through Land-Use Planning and Technology" (2010). She has been recognized for the substantial contribution to the 2007 Nobel Peace Prize (IPCC, May 2008). 